\author{
Anna BAZAN-KRZYWOSZAŃSKA ${ }^{1}$ \\ Maria MRÓWCZYŃSKA ${ }^{2}$ \\ Marta SKIBA ${ }^{3}$
}

\title{
BADANIA PERCEPCJI MIESZKAŃCÓW ZIELONEJ GÓRY - MAPY MENTALNE
}

\begin{abstract}
Artykuł przedstawia próbę zwrócenia uwagi na elementy kompozycji urbanistycznej miasta Zielona Góra, które są ważne dla jej mieszkańców. Badania percepcji umożliwiającą określenie i hierarchizację elementów przestrzennych miasta. Jako metodę badawczą przyjęto mapy mentalne tworzone przez mieszkańców. Miasto przedstawiane spontanicznie w formie graficznej, w skojarzeniach, wyróżniających elementy przestrzeni miejskiej, jest powszechnie stosowaną techniką badań. Większa część elementów i obiektów urbanistycznej kompozycji miasta powtarzała się na wszystkich mapach. Dzięki temu badaniu można określić co jest ważne i dostrzegane w przestrzeni przez jej użytkowników, a tym samym na co władze lokalne powinny zwrócić szczególną uwagę. Często wyróżniane obiekty są symbolami, punktami orientacyjnymi i elementami związanymi z wydarzeniami kulturowymi, z którymi społeczność lokalna się identyfikuje. Zapis urbanistyczny w lokalnych dokumentach planistycznych (mpzp) powinien te elementy wyróżniać i chronić.
\end{abstract}

Słowa kluczowe: percepcja, obraz miasta, mapy mentalne, Zielona Góra

\section{Wstęp}

Każdy, kto identyfikuje się z miejscem jako jego właściciel, obejmuje to swoje miejsce szczególnym rodzajem percepcji [14], troszcząc się o nie i wykazując poczucie odpowiedzialności. Można powiedzieć, że miejsce posiadające właściciela jest uporządkowane i zadbane, w odróżnieniu od niczyjego. W percepcji człowieka liczy się przede wszystkim użyteczność formy i symbo-

${ }^{1}$ Autor do korespondencji: Anna Bazan-Krzywoszańska, Uniwersytet Zielonogórski, Wydział Budownictwa, Architektury i Inżynierii Środowiska, tel. 68 3282309, a.bazan@aiu.uz.zgora.pl,

${ }^{2}$ Maria Mrówczyńska, Uniwersytet Zielonogórski, Wydział Budownictwa, Architektury i Inżynierii Środowiska, tel. 68 3282309, m.mrowczynska@ib.uz.zgora.pl,

${ }^{3}$ Marta Skiba, Uniwersytet Zielonogórski, Wydział Budownictwa, Architektury i Inżynierii Środowiska, tel. 68 3282309, m.skiba@aiu.uz.zgora.pl. 
lika. Dlatego też najwspanialsza forma pozbawiona funkcji akceptowanej oraz symbolicznych znaczeń, nie jest postrzegana i rejestrowana. Elementy obrazu jak mit, rytuał, ceremoniał społeczny są podstawą jego czytelności.

Nawyki percepcyjne najczęściej kształtują się poprzez przejmowanie wzorów od poprzedniego pokolenia, tworząc po prostu tradycję [14]. O tym, co dziś jest akceptowalne decyduje, nie tylko środowisko naturalne, sytuacja ekonomiczna, ale przede wszystkim tradycja społeczna i kulturowa, charakterystyczna dla miejsca życia. Dlatego, jeśli brakuje wokół przyjaznych i akceptowanych przestrzeni - wzrasta rola przestrzeni najbardziej prywatnych, czyli domu. Zatem niedostępne, otoczone szczelnymi, wysokimi płotami domy na wsi są wyrazem braku akceptacji dla przestrzeni przed domem, choć kontrast pomiędzy nimi a innymi obejściami, przed którymi stoją np. ławeczki, dla nie spieszących się mieszkańcy wsi, często razi.

Na współczesnych przedmieściach, w miejscach dobrze skomunikowanych $\mathrm{z}$ centrum, lokowane są podmiejskie obszary funkcjonalne. Widoczne są one z daleka. Najczęściej, stanowią one komercyjne wizytówki miast. Widoczne z głównych komunikacyjnych szlaków, przyciągają wzrok agresywnymi reklamami. Nie współgrają z otaczającym krajobrazem, zagłuszają go. Reklamami luksusowych sklepów, informują przybyszów o sile nabywczej mieszkańców miasta. Współczesny człowiek poznaje miasto nie po grubości otaczających go murów miejskich czy wysokości wieży ratusza, lecz po reklamach i ilości metrów kwadratowych powierzchni centrów handlowo-usługowych, po hektarach parkingów, które nieodłącznie im towarzyszą. Jest to skutek niekontrolowanego wzrostu miast, rezultat fali ułatwień inwestycyjnych [9].

Szansą na wzmocnienie wizerunku miast i ich korzystny odbiór może stać się większa aktywność oraz przedsiębiorczość samorządów lokalnych związana np. z kształtowaniem nowych możliwości i wzorców przybliżających wizję wspólnie kształtowanej i użytkowanej przestrzeni. Tej przestrzeni, która rozciąga się np. pomiędzy parkingiem centrum handlowego a przydomowym garażem przeciętnego mieszkańca Zielonej Góry.

\section{Symbol miejsca}

Aby zyskać akceptację społeczną wizualnej formy przestrzeni konieczne jest zbudowanie ciągłości historycznej elementów urbanistycznych wpisanych w pamięć mieszkańców. W literaturze niewiele prac odnosi się bezpośrednio do badania jakości zmienianej przestrzeni. Niemniej można dla tych celów wykorzystać wskazówki zawarte w pracach Bogdanowskiego, DąbrowskiejBudziło, Wejcherta, Wojciechowskiego, odnoszące się do percepcji, oceny jakości krajobrazu, czy budowy panoram [5,6,7,20,21]. Są one obszernie omawiane w odniesieniu do terenów zurbanizowanych. „Widoki funkcjonuja $w$ świadomości ludzkiej jako symbol danego miejsca, często z nim identyfikowany. Fragmenty przestrzeni miasta petniace role symboli sa poznawalne i identy- 
fikowane przez większość mieszkańców. Posiadaja zindywidualizowane formy, sa zaakcentowane $w$ panoramie miasta elementami pionowymi i poziomymi, dzięki nim miasto staje się tatwiejsze do odwzorowania $w$ pamięci i czytelne"[6]. "Obraz środowiska, uogólniony mentalny wizerunek materialnego świata zewnętrznego ugruntowany $w$ umyśle czlowieka, jest kluczowym ogniwem procesu poszukiwania drogi. taki obraz, który jest równocześnie bezpośrednim wrażeniem oraz wynikiem pamięci przeszłych doświadczeń, stuży do interpretowania informacji i wskazywania kierunku dziatań. Potrzeba rozpoznawania i strukturyzacji naszego otoczenia jest tak istotna i ma tak glębokie korzenie w przeszłości, że tego rodzaju obraz ma dla człowieka rozległe znaczenie praktyczne i emocjonalne"[12]. Rzeczywiście, każde miasto posiada takie charakterystyczne miejsca - symbole. Doskonałym dowodem ich istnienia są wyniki badań ankietowych przeprowadzonych przez Bagińskiego [1,2].

Istotą percepcji jest widok, który powoduje nasze zainteresowanie. Wśród wielu różnych widoków można jednak wyodrębnić te, które zapadają w pamięć jako bardziej wyraziste, oryginalne lub znaczące. Najważniejsze są wrażenia, które najsilniej oddziałują na naszą świadomość. Odbiorca architektury czy sztuki dostrzega różne jej aspekty. Czasem dostrzega piękno, innym razem oryginalność, a kiedy indziej jej chaos i brzydotę [5].

\section{Badania percepcji w literaturze}

Studia nad zapamiętywaniem drogi rozpropagowała w świecie klasyczna już praca Lyncha [12]. Autor próbował dociec, jakich fragmentów terenu ludzie nie zapamiętują i z jakiego powodu. Ustalił również, że w orientacji w przestrzeni istotną rolę pełnią:

1) "drogi (...) kanaty, wzdtuż których obserwator zwyczajowo, od czasu do czasu, albo potencjalnie się porusza(...) moga to być ulice, przejścia, pomosty, pasaze, trasy tranzytowe, kanaty, tory kolejowe",

2) "krawędzie (...) linearne elementy, których obserwator nie używa ani nie wyobraża sobie jako dróg (...) To granice między dwoma etapami; linearne przerwy w ciagłości: nabrzeża, odcinki linii kolejowych, ściany (...)",

3) "rejony (...) sa średnimi lub większymi częściami miasta, w wyobraźni posiadajacymi dwuwymiarowa powierzchnię, do wnętrza których obserwator mentalnie wchodzi i które sa rozpoznawalne, jako że posiadaja jakiś (...) identyfikujacy charakter",

4)"węzty - miejsca - strategiczne punkty miasta, do których obserwator może sie dostać i pomiędzy którymi się porusza (...) - skrzyżowania, przystanki środków transportu, punkty zbiegu dróg (...),

5) punkty orientacyjne jako typ elementu odniesienia "działajacy od zewnatrz (...) konkretny obiekt, jak budowla, szyld (...)[12];

$\mathrm{Z}$ badań Lyncha wynika, że punkty, ciągi i struktury przestrzenne z różnych względów stają się ważne dla danego człowieka lub społeczeństwa [12]. 
Mogą zapadać w pamięć ze względu na swoją formę lub funkcję, która je wyróżnia w otoczeniu. Czasem są to miejsca związane z konkretnymi wypadkami lub sytuacjami z życia ankietowanej osoby lub miejsca lokalnej tradycji, często nieczytelne dla osób "z zewnątrz".

Za paralelne do badań Lyncha można uznać analizy krajobrazowe Warszawy prowadzone pod kierunkiem Wejcherta $\mathrm{i}$ zapisywane $\mathrm{w}$ postaci tzw. „krzywej wrażeń” przez osoby poruszające się wzdłuż wybranej trasy [20]. Autor stwierdził, że szczegółowość postrzegania środowiska zależy od szybkości przemieszczania się obserwatora. Kierowcy pojazdów, z racji prędkości przemieszczania się pojazdu w którym podróżują, wykazują znacznie mniejsze, niż piesi, uwrażliwienie na występowanie elementów drobnych, finezyjnych, czy wymagających refleksji.

W innym kontekście podjął ten problem Bogdanowski opisując specyfikę, jaką tworzy więź z otoczeniem i poczucie tożsamości [5]. Akceptacja rodzimego krajobrazu powoduje odrzucanie elementów negatywnych i tworzenie swoistego stereotypu - modelu krajobrazu pozytywnego. Ponadto, jak pisze Wojciechowski na akceptację krajobrazu przez daną społeczność ma wpływ stopień „świadomości estetycznej” jej członków osiągany przez odpowiedni system edukacyjny i znajomość dziedzictwa kulturowego [21]. Uzasadnieniem mogą być badania opisane przez Nęckiego, które wykazały, że każda społeczność narodowa czy regionalna, każda klasa społeczna waloryzuje przestrzeń w odrębny, specyficzny sposób [13]. Im lepsza edukacja, tym lepsze zrozumienie form historycznych i ich znaczeń. Uczymy się nie tylko bezpośredniego użytkowania przestrzeni, ale także jej symboliki i roli, jaką ta przestrzeń odgrywa w relacjach społecznych formalnych i nieformalnych. Środowisko ma swoją historię użytkowania i jeżeli nie istnieją specjalne powody do zmiany interpretacji danej przestrzeni, to przeważnie kontynuuje się (dziedziczy) dotychczasowy sposób jej użytkowania [14].

Większość badań w wielu kategoriach dyscyplinarnych m.in.: krajobrazie, geografii, leśnictwie, rekreacji, ochronie środowiska i zachowaniach behawioralnych i interdyscyplinarnych, dotyczy paradygmatu eksperta i paradygmatu psychofizycznego. Odzwierciedla to działalność wielu profesjonalistów, którzy korzystają ze swojego wykształcenia i charakteru praktyk zawodowych (architekci, planiści ale i menadżerowie zarządzający turystyką i rekreacją) [24]. Niewiele jest artykułów w czasopismach dotyczących postrzegania krajobrazu, gdzie nacisk kładzie się na psychofizyczne i poznawcze podejście odbioru. Wiele natomiast artykułów zawiera krytykę empirycznych badań, sposobu oceny percepcji, dyskusji dotyczących dopasowywania technik do konkretnych problemów i teoretycznych dyskusji metodologicznych na ten temat [17]. Każda krytyka zapewnia konkretne propozycje dla poprawy metod, być może nieuchwytnego, optymalnego sposobu oceny [16]. 


\section{Obraz miasta}

Istotnie, pojęcia tworzone przez psychologów trudno jest zwykle odnieść do bardziej fundamentalnych, mierzalnych cech związanych $\mathrm{z}$ pracą mózgu. Ciekawy jest pomysł przedstawiony przez Ducha, związany z procesami poznawczymi i preferowanym sposobem postrzegania, opartym na konkretnym doświadczeniu lub abstrakcyjnym myśleniu, oraz sposobie działania, z wykorzystaniem eksperymentu albo obserwacji refleksyjnej [8]. Opisał on model, w którym rozróżnia 3 typy aktywności mózgu:

1) procesy na poziomie kory analizującej dane zmystowe $S$, gdzie powstają wzorce aktywności konieczne do rozróżniania dźwięków, kształtów, wrażeń dotykowych itd. (głównie kora wzrokowa, słuchowa, czuciowa);

2) procesy centralne $\mathrm{C}$, związane $\mathrm{z}$ abstrakcyjnymi pojęciami, które nie mają silnych składowych zmysłowych i angażują głównie korę skojarzeniową (ciemieniową, skroniową i przedczołową).

3) procesy motoryczne, związane $\mathrm{z}$ aktywacją kory ruchowej, wyobraźniq ruchowa jak i fizycznymi manipulacjami (głównie kora czołowa, jądra podstawy, móżdżek) [8].

Mapa poznawcza może być zatem równoznaczna z określeniem wyobrażenia przestrzeni miejskiej. Teoria wysnuta na obserwacji, że długotrwały związek mieszkańca $\mathrm{z}$ określonym terenem prowadzi do powstania doświadczeń, które zapisywane są w pamięci w postaci wyobrażeń czasu i przestrzeni.

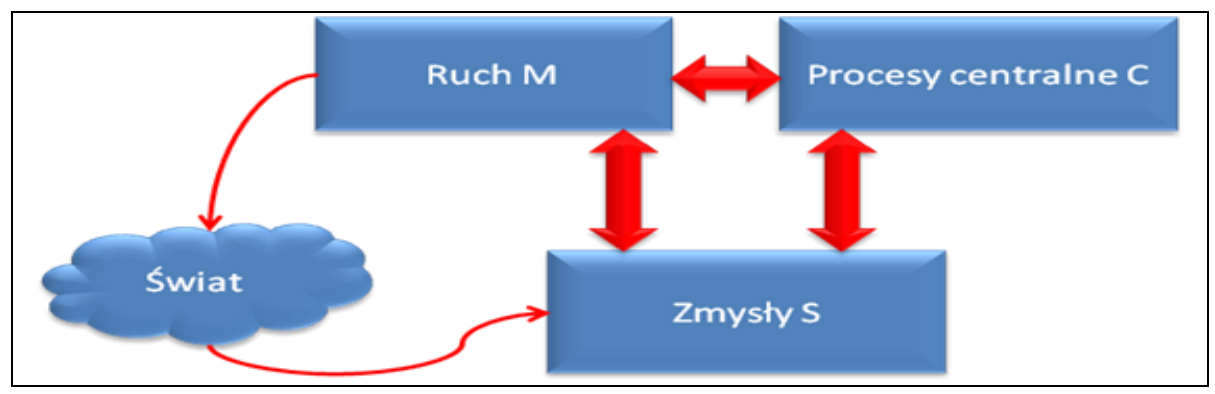

Rys. 1. Model aktywności mózgu wg Ducha [8]. Autorzy

Fig. 1. Model of brain activity by Duch [8]. Authors

Wiele procesów poznawczych - percepcja niejednoznacznych obrazów, przypominanie, planowanie, rozwiązywanie problemów, spontaniczna aktywność, daje się przedstawić w 3 krokach:

1) przygotowanie mózgu i uświadomienie sobie zadania;

2) oczekiwanie na pojawienie się nieświadomych skojarzeń, które pozwolą zrobić krok w kierunku rozwiązania;

3) świadome dostrzeżenie najciekawszych skojarzeń. 
Według Ducha uczenie się nowych rzeczy musi się opierać na wcześniej zdobytej wiedzy. Podstawą jest istniejąca struktura pojęć i relacji między nimi (transformacji). To przestrzeń, w której pojawić się powinny nowe elementy. Jeśli jednak nie ma na czym się oprzeć uczenie nie będzie efektywne, pozostanie na poziomie formułek przechowywanych w pamięci [8].

\section{Metoda badawcza}

Metodą badawczą było sporządzanie map mentalnych, które w odróżnieniu od ankiety ustnej, gdzie sposób zadawania pytań i ich kolejność mogą sugerować odpowiedź, nie posiada tej wady $[3,12,15]$. Można je wykonać dla praktycznie wszystkich dziedzin i sytuacji, w których planuje się twórcze odniesienie do jakiegoś zagadnienia [10]. Można w ten sposób ukazać połączenia pomiędzy pojęciami i zorientować się w aspektach treści (np.: ukazać zabarwienie emocjonalne). W trakcie zapamiętywania powstaje mapa umysłowa - jako subiektywny schemat obiektów i relacji między nimi [13]. Wiadomo, że uczenie się rozkładu przestrzennego przebiega względnie szybko, tak że każde następne spotkanie $\mathrm{z}$ określonym środowiskiem jest ułatwione poprzez pamięć poprzednich. Odbiór nie pojedynczego wnętrza lecz całych sekwencji widoków staje się mimo woli podstawą kształtowania w świadomości mapy mentalnej otoczenia[5].

Artykuł prezentuje wyniki badań przeprowadzonych w 2015 roku w Zielonej Górze. Grupa badawcza składała się z 60 studentów I roku studiów magisterskich Kierunku Architektura i Urbanistyka Uniwersytetu Zielonogórskiego, którzy w grupach trzy osobowych sporządzali mapy Zielonej Góry.

Badania map wyobrażeniowych polegają na analizie dokumentów wykonanych przez respondentów. Były to albo mapy (szkice), albo opisy słowne do hasła Zielona Góra. W przypadku mapy analizowany jest sposób wykonywania rysunku, orientacja rysunku, wzajemne ułożenie obiektów, obecność lub brak pewnych elementów, powiększenie lub pomniejszenie niektórych obszarów. W badaniu opisów zwraca się szczególną uwagę na wartości przypisywane niektórym miejscom.

\section{Zielona Góra}

Zielona Góra znana jest jako miasto o bogatych tradycjach winiarskich, które dziś żyją w historii i kulturze, a w przeszłości obecne były w gospodarce i krajobrazie przestrzennym. Oficjalnym miejskim świętem Winobranie stało się w roku 1852, co urzędowo ogłosił magistrat. Uprawa winogron opłacała się z powodu dość łagodnego klimatu, który charakteryzuje się cechami mikroklimatu zwłaszcza na obszarze wzgórz, gdzie zmniejszone są amplitudy dobowe i występują bardzo ciepłe noce (średnio w miesiącach półrocza letniego o 0,5 do $1,5^{\circ} \mathrm{C}$ cieplejsze niż w Poznaniu, Wrocławiu, czy Słubicach). Obszar miasta 
Zielonej Góry charakteryzuje się też niższą liczbą dni z przymrozkami niż obszary wokół miasta, położone niżej.

Granice administracyjne miasta obejmują: miasto - historyczne centrum wraz z nowymi osiedlami mieszkaniowymi i strefą przemysłową oraz pierścień lasów, a od 1 stycznia 2015 roku także gminę wiejską. Rozwój miasta następuje na zewnątrz terenów zurbanizowanych poprzez stopniowe rozlewanie się wzdłuż szlaków komunikacyjnych oraz wycinkę drzew.

Centrum miasta położone jest w niewielkim obniżeniu w stosunku do osiedli mieszkaniowych położonych na wzniesieniach. Osiedla mieszkaniowe charakteryzują się wysoką zabudową od 5 do 11 kondygnacji i dużą intensywnością zabudowy. Najczęściej graniczą one bezpośrednio z terenami lasów, które traktowane są jako zieleń uzupełniająca i rekreacyjna. Zabudowa 11 kondygnacyjna wyraźnie góruje wysokością $\mathrm{w}$ panoramie miasta, widocznie wystając ponad lasy. Wzrost intensywności i wysokości zabudowy dominuje w pasie południowo-zachodnim miasta.

Informacją wizualną dla użytkownika przestrzeni miejskiej jest praktycznie wszystko: formy elementów naturalnego środowiska miejskiego, ukształtowanie powierzchni terenu, cieków i zbiorników wodnych, zieleni, nieboskłonu, a także zbiorowiska ludzkie wypełniające przestrzenie publiczne. Wpływ na odbiór informacji mają poszczególne obiekty, nawierzchnie ulic, małe formy architektoniczne i inżynierskie, pomniki i rzeźby. Ułatwiają one orientację w układzie przestrzennym miasta, określają charakter i funkcję różnych elementów zabudowy miejskiej, dostarczają informacji kulturalnych, handlowych i usługowych, zawiadamiają o wydarzeniach codziennego życia. Dzięki temu odbiera się panoramę miasta (np. ze wzgórz lub punktów widokowych, których w Zielonej Górze nie brakuje) - jako jego wizytówkę.

Współczesne miasta o tradycyjnym układzie w centrum, takim jak Zielona Góra, obrastają nowymi układami komunikacyjnymi, a w swoich strefach peryferyjnych nowymi strukturami przestrzennymi, związanymi z centrami handlowo-usługowymi, rekreacyjnymi, edukacyjnymi. Te nowe układy, najczęściej bezkształtne, zdominowane są przez infrastrukturę związaną z ruchem samochodowym. Wyróżnia je najczęściej zła definicja miejsca, brak granic i czytelnej symboliki ułatwiającej poruszanie się w obszarze zurbanizowanym. Wszystko to nie sprzyja czytelności kompozycji układów miejskich, nie ułatwia orientacji w przestrzeni. Poza tym nie rodzi związków emocjonalnych, poczucia ładu i tożsamości z miejscem.

Codzienna przestrzeń mieszkańca to przestrzeń oddziaływań informacyjnych, bezustannie weryfikowanych przez człowieka podczas obserwacji. W następstwie wszechobecnych masowych środków przekazu współczesny człowiek dysponuje specyficznym rodzajem wrażliwości zmysłowej: postrzegania w codziennym życiu tego co niezwykłe i zaskakujące [18]. Odbiorca współczesny, w coraz większym stopniu, potrzebuje przyswajania wszelkich informacji za pomocą obrazów. Potrzebę tę zaspokajają nie tylko telewizja, ki- 
no ale również komputer, plakaty, plansze reklamowe, ilustracje. Obraz i cała ikonosfera przynoszą natychmiastowy rezultat myślowy i wyobrażeniowy, są maksymalnie syntetyczne, przedstawiają daną informację od razu i w całości. Fakt ten pociąga za sobą zmianę sposobów myślenia - rodzą się skojarzenia wywołane przez zbiory obrazów, odczucia natury emocjonalnej i intuicyjnej [18]. Wpływ na odbiór informacji mają poszczególne obiekty, nawierzchnie ulic, małe formy architektoniczne i inżynierskie, pomniki i rzeźby, a także zbiorowiska ludzkie wypełniające przestrzenie publiczne. Ułatwiają one orientację w układzie przestrzennym miasta, określają charakter i funkcję różnych elementów zabudowy miejskiej, dostarczają informacji kulturalnych, handlowych i usługowych, zawiadamiają o wydarzeniach codziennego życia.

Społeczny sposób wytwarzania przestrzeni, uwzględniając „dialekt trwania”, zakłada że przestrzeń to „trwała pamięć społeczeństwa”. „Wszelkie miasto ... jako napięta społeczność ze swoimi kryzysami, przerwami, katastrofami ... musi być umieszczone i rozumiane $w$ kompleksie otaczajacych je wsi i archipelagów sasiednich miast ... musi zatem być usytuowane w ożywiajacym ten kompleks ruchu, mniej czy bardziej sięgającym w przeszłość, niekiedy sięgajacym bardzo odlegtych rejonów czasu" [4]. Przestrzeń abstrakcyjna idea (matematycznie) wtasność materii (fizycznie) środowisko naturalne wyksztatcone $w$ określony sposób w toku ewolucji (przyrodniczo) twór ludzki, antropogeniczny, kulturowy $i$ społeczny, tworzony przez jednostki, grupy i zbiorowości ludzkie (społecznie, kulturowo).

Leszkowicz - Baczyńska Ż., Machaj I. i Zdulski M., w 1998 r., przeprowadzili za pomocą wywiadu, badania pod tytułem „Zielona Góra 98 - dziś jutro miasta w oczach mieszkańców" [23]. Całość oparta została na porównaniu zgodności wyników przeprowadzonych wywiadów z zapisami Studium uwarunkowań i kierunków zagospodarowania przestrzennego miasta Zielona Góra. Wynikiem badania stała się diagnoza świadomości mieszkańców odnośnie życia społecznego, z określeniem preferowanych przez nich przeobrażeń funkcji miasta. Badający stwierdzili między innymi, że mieszkańcy mimo deklaracji odnoszącej się do znajomości miasta, nie potrafili określić jego granic. Próba wyjaśnienia tego mechanizmu oparta została na teorii Lyncha [12], który twierdzi, iż granicę dla obserwatora stanowią elementy linearne przestrzeni, takie jak linia kolejowa, ogrodzenie czy autostrada. Dodatkowo odczucie to potęgują elementy nieprzekraczalne poprzecznie. Zielonej Górze brak wyrazistych granic. Fizycznie tworzą je ściany lasu i łąki. Badając, jak mieszkańcy Zielonej Góry strukturalizują miasto, wykazano iż niezależnie od określeń urbanistów, dzielących miasto $\mathrm{w}$ studium na zespoły dzielnicowe, przeciętny mieszkaniec widzi je w ramach osiedli mieszkaniowych. 


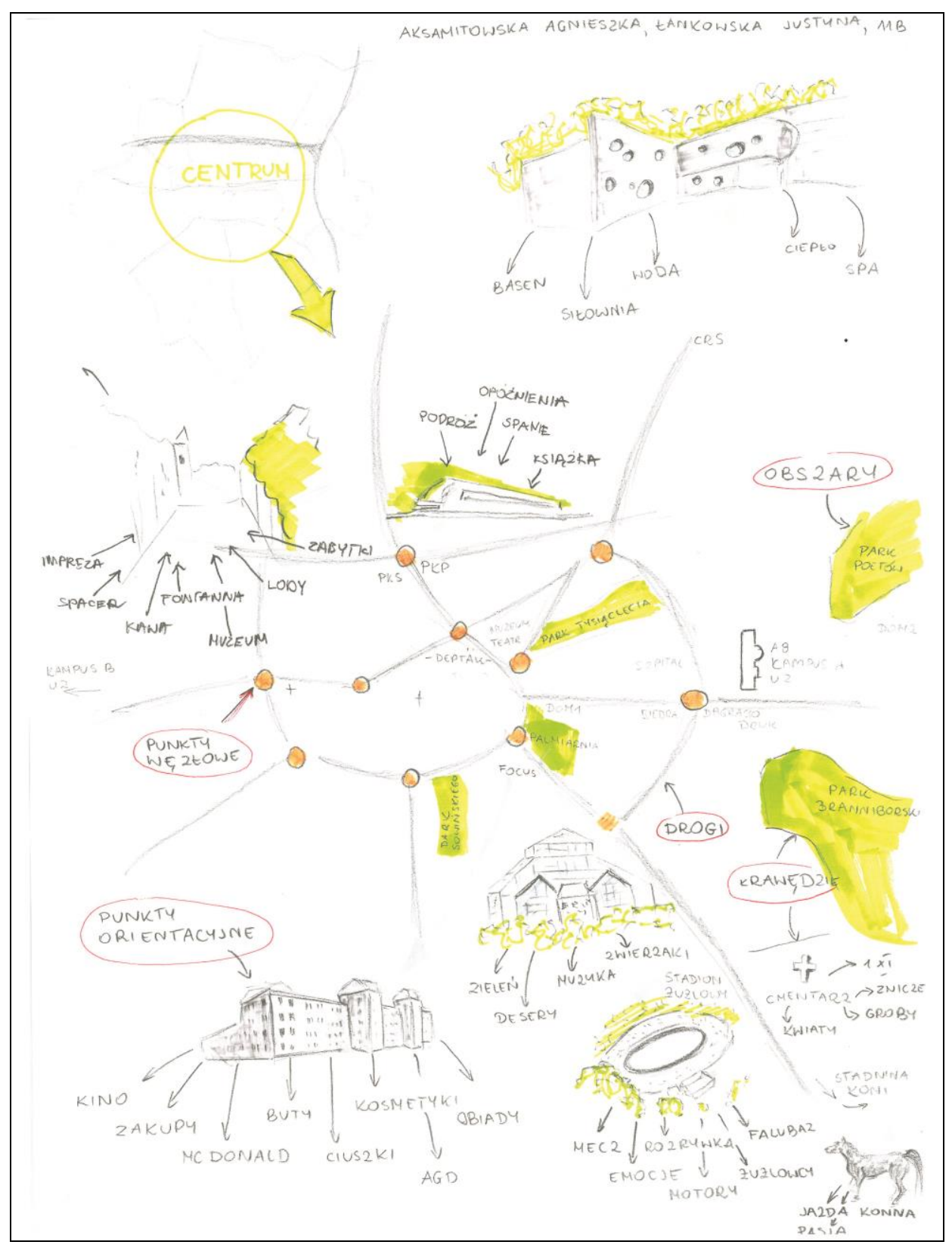

Rys. 2. Przykład mapy mentalnej wykonanej przez studentów Uniwersytetu Zielonogórskiego

Fig. 2. Example mental map made by students of the University of Zielona Góra 


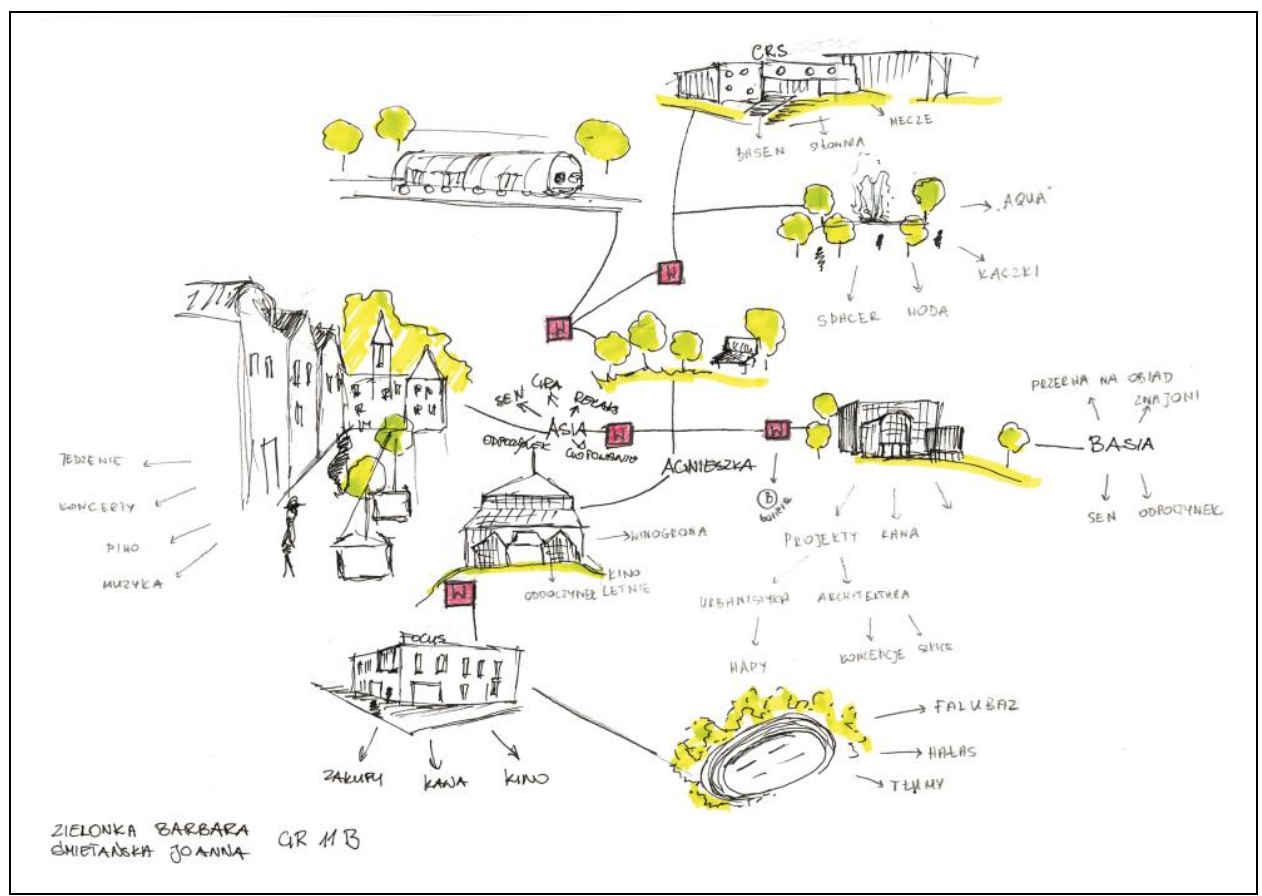

Rys. 3. Przykład mapy mentalnej wykonanej przez studentów Uniwersytetu Zielonogórskiego

Fig. 3. Example mental map made by students of the University of Zielona Góra

\section{Wnioski z badania}

Mapy mentalne dla miasta Zielona Góra, wskazują zbiór luźnych wyobrażeń i kojarzeń dotyczących przestrzeni miasta. Wyrażają dostrzegane, przez użytkowników przestrzeni miasta, znaki - obraz zależny jest od sposobu wykorzystywania przestrzeni, wybieranego środka transportu komunikacyjnego, miejsca zamieszkania, jak też sposobu obserwacji i postrzegania. Przyjąć należy iż przeciętny mieszkaniec zna dobrze tylko niewielki fragment swojego miasta, zwłaszcza ten z najbliższego otoczenia lub ten, który często odwiedza albo po prostu uznaje za ważny. Bo czym innym można wytłumaczyć, że stare miasto z długim deptakiem, tak charakterystyczne dla Zielonej Góry znalazło wyraz w odpowiedziach studentów rzadziej niż Centrum Rekreacyjno Sportowe czy stadion żużlowy. Znakiem czasu jest patrzenie na miasto $\mathrm{z}$ okien samochodu czy autobusu i częste odwiedzanie centrów handlowych - CH Focus Mall Zielona Góra. Podmiejskie strefy funkcjonalne w postaci centrów handlowych, edukacyjnych czy rekreacyjnych wraz z szybkimi trasami dojazdowymi to współczesne bramy miasta. Pełnią rolę dominant przestrzennych widocznych w reklamach z daleka. One pozwalają na szybką orientację przestrzenną, pełnią 
funkcję znaczników - miejsca spotkań. W głównej mierze determinują też nasz wizerunek miasta, w tym jego ład i porządek w ukształtowaniu przestrzennym oraz jakość kształtowanej architektury. Studenci za pomocą swoich map zaprezentowali obraz miasta Zielona Góra (patrz rys. 2, 3), wyszczególniając miejsca mające dla nich znaczenie $\mathrm{w}$ obrazie ogólnym tej przestrzeni. $\mathrm{W}$ ich pracach miejsca nauki, sportu i rekreacji z którymi wiąże się ich czas mają główne odzwierciedlenie.

\section{Dyskusja}

Przestawieni w badaniach literaturowych badacze wyróżniali dwa podstawowe sposoby organizacji informacji przestrzennych: sekwencyjny (liniowy) oraz przestrzenny $[5,6,7,10,12,20]$. Ten pierwszy używany był w obszarach słabo znanych, gdzie znane były obiekty jedynie wzdłuż pewnych tras. I drugi, gdy lepiej poznany obszar informacji przestrzennych był systematyzowany, tworząc sieć powiązanych ze sobą obiektów.

Warunkiem akceptacji zmian wprowadzonych w przestrzeni jest rozpoznawanie elementów, stanowiących w oczach mieszkańców o tożsamości miasta. Traktując krajobraz urbanistyczny jako dobro publiczne łatwo dostrzegamy, że nie da się go chronić lub upiększyć bez zrozumienia i woli mieszkańców [14]. Widać zatem ogromną potrzebę kontaktowania się z miejscową ludnością na różnych etapach planowania i projektowania. Znając przekonania i szanując to, co cenne, można podjąć dialog i promować odpowiednie walory widokowe, choćby przez prasę, radio i telewizję lokalną [18].

Z zaprezentowanych prac wynika, że proces postrzegania środowiska stał się jednym z istotnych elementów programów badań tzw. ,jakości życia” [22]. Problem doboru i stosowania odpowiednich metod oceny jakości przestrzeni oraz problem kształtowania się odczucia tej jakości stanowi funkcję percepcji, której istotą jest suma odebranych bodźców środowiska, możliwych do przetworzenia, narastająca od poczucia spokoju, piękna do satysfakcji i tożsamości z prezentowanym krajobrazem [22].

\section{Wnioski}

Celem prezentowanych przez autorki i podobnych badań w literaturze przedmiotu jest stworzenie narzędzi pomocnych $\mathrm{w}$ opracowaniu np. planów poprawy atrakcyjności miast, wykorzystujących szanse stworzone choćby przez Unię Europejską w zintegrowanych programach operacyjnych rozwoju regionalnego (zasady polityki regionalnej w Unii Europejskiej zostały dostosowane do zapewnienia zrównoważonego postępu ekonomicznego i socjalnego we wszystkich państwach). Opisana metoda sporządzania map mentalnych może i powinna być pomocna w zdobyciu wiedzy koniecznej dla uzyskania akceptacji społecznej wszelkich planów inwestycyjnych, w tym dotyczących realiza- 
cji inwestycji o charakterze celu publicznego. Krajobraz naszego codziennego życia składa się nie tylko z ludzi spotykanych na naszej trasie od przystanku, sklepu, kiosku do pracy, ale i z przestrzeni, w której znajdują się konkretne charakterystyczne dla danej przestrzeni urbanistycznej obiekty. Przestrzeni, którą powinniśmy uważać za bezpieczną i własną, w której każde dzieło architektury jest nie tylko przedmiotem materialnym ale szczególnym zapisem myśli i dążeń swego twórcy. Choć nie zawsze, zgodne z jego intencją, postrzeganie jest przez odbiorców.

W każdym mieście istnieją elementy architektoniczne i urbanistyczne, które podlegają oglądowi i ocenie z perspektywy mieszkańca, ale także przybysza. Oceny te mogą bardzo różnić się od ocen profesjonalistów: urbanistów czy planistów przestrzennych. Każdy, niezależnie czy identyfikuje się z miastem czy nie, poznaje i przyswaja sobie jego obraz. Interesującym jest nie tylko sam obraz tej przestrzeni, ale także proces jego przyswajania. W badaniach ankietowych forma zadawania pytania może sugerować sposób jej waloryzacji. Żeby tego uniknąc przyjęto formę rysunkową, a zadaniem było narysowanie z pamięci planu Zielonej Góry. Taka forma badania mapy mentalnej, jako pozbawiona zabarwienia emocjonalnego, sprowadza się do pamięciowego odtworzenia najlepiej poznanych fragmentów miasta. Zapewne są to ślady najczęstszych wędrówek po mieście.

Jednym z instrumentów polityki lokalnej, w której wspólne dobro, jakim jest obraz naszego miasta, powinno być zabezpieczone, jest nie tylko miejscowy plan zagospodarowania przestrzennego czy studium uwarunkowań i kierunków rozwoju ale i strategia rozwoju miasta. Tu powinny znaleźć wyraz wyniki badań i studiów wpływające bezpośrednio na kształt zagospodarowywanej przestrzeni, także ankietowe badania preferencji mieszkańców, wykonane $\mathrm{np}$. W oparciu o mapy mentalne, prezentujące nie tylko wieloletnią politykę przestrzenną ale i nawyki mieszkańców.

Społeczeństwo ocenia architekturę według pewnych stereotypów, które zmieniają się podobnie jak dominujące formy przestrzeni publicznych. Modele kompozycji miejskich takich jak rynek z ratuszem i kościołem to nie tylko kulturowe dziedzictwo ale i dowód, że każda epoka zapisuje się w swoich dziełach na swój własny, niepowtarzalny sposób. Współczesne formy wieżowców, centrów handlowych i autostrad powstały pod wpływem istniejących warunków, w szczególności wymagań funkcji i stosowanych konstrukcji. Co właściwie potwierdziły przeprowadzone badania obrazu Zielonej Góry.

\section{Literatura}

[1] Bagiński E., Zarys metod, technik i wyników badań, oraz Teoretyczne podstawy przyczynkowych rozważań nad przestrzenią w aspekcie społeczno-kulturowym, w: Planowanie przestrzenne, zarys metod i technik badawczych red. E. Bagiński, Oficyna Wydawnicza Politechniki Wrocławskiej, Wrocław 1994. 
[2] Bagiński E., Preferencje mieszkaniowe ludności miasta średniej wielkości ( na przykładzie Zielonej Góry ), Prace Naukowe Instytutu Historii Architektury, Sztuki i Techniki Politechniki Wrocławskiej, Wydawnictwo Politechniki Wrocławskiej, Wrocław 1992.

[3] Bańka A., Społeczna psychologia środowiskowa. Scholar, Warszawa 2002.

[4] Braudel F., Historia i trwanie, Czytelnik, Warszawa, 1971.

[5] Bogdanowski J., Droga od percepcji do ochrony i kształtowania krajobrazu, w: O percepcji środowiska(pr. zbior.), Zeszyty Naukowe 9, Instytut Ekologii, Oficyna Wydawnicza PAN, 1994.

[6] Dąbrowska-Budziło K., Studia widokowe w planach zagospodarowania przestrzennego w: Czasopismo Techniczne 1A/1998, Wydawnictwo Politechniki Krakowskiej, Kraków 1995.

[7] Dąbrowska-Budziło K., Walory widokowe krajobrazu, w: Architektura krajobrazu a planowanie przestrzenne, red. K. Pawłowska, Politechnika Krakowska, Kraków 2001.

[8] Duch W., Mózgi i Edukacja: w stronę Neurokognitywnej Fenomiki. W: Informatyka w Edukacji, lipiec. Toruń, 2013.

[9] Jastrząb T., Przestrzenie publiczne we współczesnej urbanistyce i architekturze. Wydawnictwo Politechniki Poznańskiej, 2004.

[10] Kozak W., Mapa mentalna czyli twórcza technika notowania, Kielce 1999.

[11]Lewicka M., Psychologia miejsca. Scholar, Warszawa, 2012.

[12] Lynch K., Obraz miasta, Wydawnictwo Archivolta Michał Stępień, Kraków 2011.

[13] Nęcki Z., Percepcja środowiska - ujęcie psychologiczne, w: O percepcji środowiska(pr. zbior.), Zeszyty Naukowe 9, Instytut Ekologii, Oficyna Wydawnicza PAN, 1994.

[14]Pawłowska K., Idea swojskości, Wyd. Politechniki Krakowskiej, Kraków 2001.

[15]Skiba M., Obraz Zielonej Góry w badaniach preferencji mieszkańców, na podstawie map mentalnych sporządzonych przez studentów Uniwersytetu Zielonogórskiego", w: Czasopismo Techniczne : Architektura, , z. 11-A, Kraków 2005, s. 392-395.

[16]Stamps A. E., 2004. Mystery, complexity, legibility and coherence: A metaanalysis. Journal of Environmental Psychology 24, s. 1-16.

[17]Stamps A. E., Nasar J. L., 2005. Using Pre-construction validation to regulate urban skylines. Journal of the American Planning Association Vol. 71, No. 1, s.73-91.

[18]Szolginia W., Informacja wizualna w krajobrazie miejskim, WFiA, 1980.

[19]Wallis A., Społeczna anatomia mieszkania w: Miasto i przestrzeń, Warszawa 1977.

[20]Wejchert K., Elementy kompozycji urbanistycznej, Wydawnictwo Arkady, Warszawa 1974.

[21]Wojciechowski K., O przydatności badań percepcji krajobrazu, w: O percepcji środowiska(pr. zbior.), Zeszyty Naukowe 9, Instutyt Ekologii, Oficyna Wydawnicza PAN, 1994.

[22]Ziobrowski Z., Mierniki jakości przestrzeni miejskiej, IGPiK, CPBR Warszawa 1992.

[23]Zielona Góra. Socjologiczne studium miasta i jego mieszkańców. Pod red. I. Machaj, Oficyna wydawnicza Impuls, Kraków 2001.

[24]Zube E., Sell J. Taylor J., 1982. Landscape perception: research, application and theory. Landscape Planning 9, s. 1-33. 


\section{PERCEPTIONS OF RESIDENTS CITY ZIELONA GÓRA - MENTAL} MAPS

\section{S u m m a r y}

The article presents an attempt to draw attention to the elements of the urban composition city Zielona Gora, which are important for people. Perception study helps in identify and hierarchy of spatial elements of the city. The research method adopted mental maps which was created by the residents. The city presented in graphical case elements of urban space is a commonly used technique research. The greater part of the elements and main urban objects are repeated on all maps. With this test you can determine what is important and perceived in space by its users and what local authorities should pay particular attention. Very often it turned out that drawn by the respondents elements are symbolic objects or elements of related cultural events, important for the residents of the city. It shows that local urban planning documents (Master Plan) should stand and protect objects or spaces this elements .

Keywords: perception, city image, mental maps, Zielona Gora

Przestano do redakcji:30.05.2015

Przyjęto do druku:10.01.2016

DOI: $10.7862 / \mathrm{rb} .2015 .175$ 